\title{
Identifying Differences in Values: Comparison between Iran and Poland
}

\begin{abstract}
Afsaneh Yousefpour*
\section{Summary}

Values are the central features of societies and they are one of the essential elements in culture. The main aim of this research was examining the differences in basic human values in Iran and Poland, taking into the account sociodemographic variables (gender, age, and education level). Analyses were performed on data coming from the fifth wave of the World Value Survey (2005-2009). The results indicated that Iranians were more likely to embrace power, security, conformity, and universalism values. Poles, on the other hand, reported higher importance of stimulation, hedonism, achievement, tradition, and benevolence values. Age moderated the relationship between country and self-direction, power, and benevolence values. Education moderated the relationship between country and tradition value.
\end{abstract}

Keywords: Schwartz's Basic Human Values, World Value Survey, Iran, Poland, culture

JEL: J28, Z13, M14

\section{INTRODUCTION}

For more than two decades, Schwartz's value model (1992, 1994, 2005a) has been used in various studies across the world (e.g., Blisky, Janik and Schwartz, 2011; Cieciuch and Davidov, 2012; Schwartz and Rubel_Lifschitz, 2009; Fontaine, Poortinga, Delbeke and Schwartz, 2008). Values are trans-situational goals, which act like directorial principles in people's lives (Schwartz, 1992; Rokeach, 1973). Each nation can be differentiated by a distinctive culture and values (Schwartz, 1992), so it is of importance - also from an organizational perspective - to study the values across different nations and cultures. These personal values are standing behind people's approaches (e.g., Dobewall and Rudnev, 2014; Vauclair, Fischer, et al., 2015), feelings (e.g., Roccas and McCauley, 2004; Sortheix and Lonnqvist, 2014), and conducts (e.g., Fischer and Boer, 2015; Verplanken and Holland, 2002).

Majority of earlier researches has concentrated on scrutinizing sociodemographic variables in order to envision people's priorities in values. However, research that examines the moderating role of education and age between country and human basic values is scarce. In addition, studies that attempt to study the primacy of human values on both individual and country level are truly limited.

In the current study I investigate three demographic variables: country, age, and education as predictors of human values. Specifically, I address the differences in basic human values between Iran and Poland - a comparison that has not been undertaken in previous studies. Additionally, I check how human values in these two countries vary as a result of age (socialization if different sociopolitical contexts) and the level of education. 


\section{LITERATURE REVIEW}

\section{Schwartz's individual values model}

Theory of basic human values, presents ten comprehensive values (Table 1), which were developed in a circular structure. This circle determines the conflicting and congruent relations of values (Figure 1) (Schwartz, 1994; Schwartz and Huismans, 1995). For instance, openness to change (selfdirection and stimulation), is in contrast with conservation (tradition, conformity and security), while self-enhancement (power and achievement) is in conflict with self-transcendence (universalism and benevolence).

Table1. Types of Motivational Values with representing definitions, single Values and their goals

\begin{tabular}{|c|c|}
\hline $\begin{array}{c}\text { Power } \\
\text { (Importance of being very rich) }\end{array}$ & $\begin{array}{l}\text { Social status and prestige, control or dominance over people and resources } \\
\text { (social power, authority, wealth, preserving my public image, social recognition) }\end{array}$ \\
\hline $\begin{array}{l}\text { Self-direction (Importance } \\
\text { of adventures and taking risks) }\end{array}$ & $\begin{array}{l}\text { Independent thought and action-choosing, creating, exploring (freedom, } \\
\text { independent, choosing own goals, creativity, curious, self-respect) }\end{array}$ \\
\hline $\begin{array}{l}\text { Achievement (Importance of } \\
\text { being very successful) }\end{array}$ & $\begin{array}{l}\text { Personal success through demonstrating competence according to social standards } \\
\text { (successful, capable, ambitious, influential, intelligent) }\end{array}$ \\
\hline $\begin{array}{l}\text { Stimulation (Importance of } \\
\text { thinking up to new ideas) }\end{array}$ & Excitement, novelty and challenge in life (daring, a varied life, an exciting life) \\
\hline $\begin{array}{l}\text { Hedonism (Importance of having } \\
\text { a good time) }\end{array}$ & $\begin{array}{l}\text { Pleasure and sensuous gratification for oneself (pleasure, enjoying life, self- } \\
\text { indulgence, sexuality) }\end{array}$ \\
\hline $\begin{array}{l}\text { Security (Importance of living } \\
\text { in a secure surroundings) }\end{array}$ & $\begin{array}{l}\text { Safety, harmony, and stability of society, of relationships and of self (national } \\
\text { security, social order, sense of belonging, family security, clean, reciprocation } \\
\text { of favors, healthy) }\end{array}$ \\
\hline Tradition (Importance of tradition) & $\begin{array}{l}\text { Respect, commitment and acceptance of the customs and ideas traditional culture } \\
\text { or religion provide (humble, devout, respect for tradition, moderate, detachment, } \\
\text { accepting my portion in life) }\end{array}$ \\
\hline $\begin{array}{l}\text { Conformity (Importance } \\
\text { of behaving properly) }\end{array}$ & $\begin{array}{l}\text { Restraint of actions, inclinations, and impulses likely to upset or harm others } \\
\text { and violate social expectations or norms (obedient, politeness, honoring parents } \\
\text { and elders, self-discipline) }\end{array}$ \\
\hline $\begin{array}{l}\text { Benevolence (Importance } \\
\text { of helping the people) }\end{array}$ & $\begin{array}{l}\text { Preservation and enhancement of the welfare of people with whom one is in } \\
\text { frequent personal contact (helpful, honest, forgiving, loyal, responsible, true } \\
\text { friendship, mature love) }\end{array}$ \\
\hline $\begin{array}{l}\text { Universalism (Importance } \\
\text { of looking after environment) }\end{array}$ & $\begin{array}{l}\text { Understanding, appreciation, tolerance \& protection for the welfare of all people } \\
\text { and for nature (broad-minded, social justice, equality, a world at peace, a world } \\
\text { of beauty, unity with nature, protecting the environment, wisdom) }\end{array}$ \\
\hline
\end{tabular}

Note: Adapted from Schwartz and Huismans, 1995 and Schwartz, 1994.

The general pattern of conflicting and congruent relationship between values has been drawn below (Figure 1). Those values that have conflicting relations are opposite to each other, and values that are congruent are placed next to each other. This model has been tested in 74 countries among 220 samples, which can confirm the universality of these ten motivational values and the circular structure of relations among them (Schwartz, 2006; Schwartz and Bardi, 2001; Schwartz and Sagiv, 1995; Schwartz, Caprara and Vecchione, 2010). 
Figure 1. Model of relations among ten motivational types of values

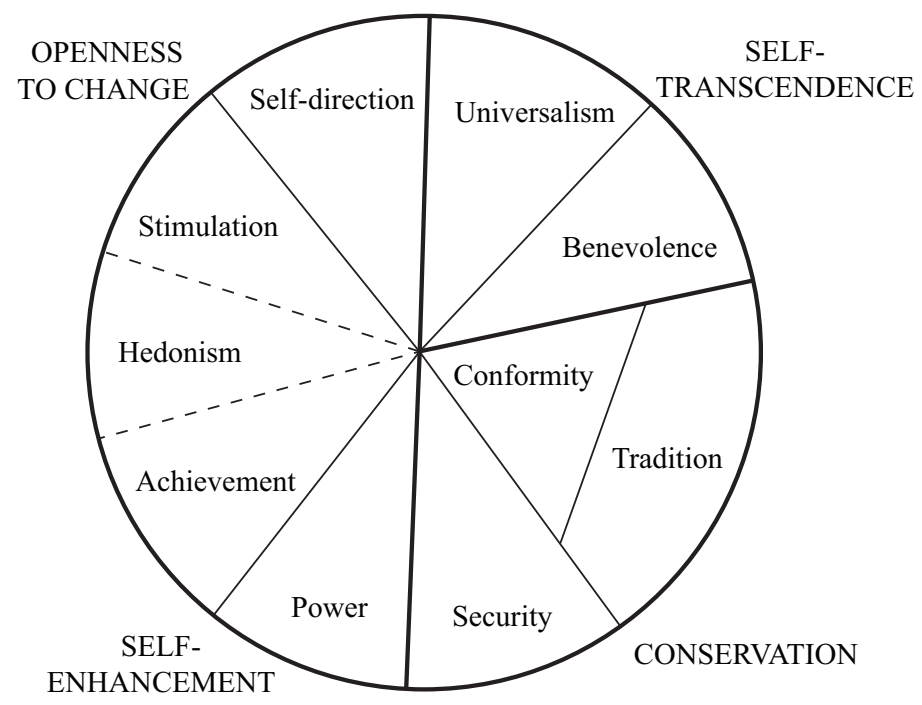

Source: Schwartz, 1994

Human values differ among people of different ages, stemming from different conditions in which they were raised. Similarly, educational experiences can also boost the intellectual openness, flexibility, and attitudes towards the importance of adventures and taking risks. Additionally, educational experiences challenge the importance of behaving properly and the importance of tradition, questioning dominant norms and outlooks (Kohn and Schooler, 1983; Prince-Gibson and Schwartz, 1998). Consequently, study of values should take into account age and education.

\section{Cultural Differences in Human Values - Iran vs. Poland}

Prior research suggests that some differences in values can be traced back to differences in cultures (Schwartz, 1992, 1994; Schwartz and Sagiv, 1995). For instance, Eastern European countries show a significant deviance from the value model proposed by Schwartz (Schwartz and Bardi, 1997, Bardi and Schwartz, 1996). For instance, there is a relationship between the importance of looking after environment and the importance of living in secure surroundings values in Eastern Europe, even though these values are generally opposite to each other. These differences are possibly stemming from the impact of communism on citizen basic values, affecting citizens' ideology and political atmosphere.

A similar impact might have been observed in Iran. Latest socio-political transformations in Iran's governance structure might have affected people's values. In Islam materialism has been condemned, therefore, we can expect that the meaning of "the importance of being very successful" and "self-transcendence" might be getting closer to each other, instead of being against each other. This can also be observed in the speeches of Supreme Leader of Iran, in which he states that every country has a special meaning for the importance of being very successful. In Islamic Iran this is not only about material issues, but also about spiritual aspects. Furthermore, in Islam being ultraconservative is not accepted, as a result, it can be expected that the importance of living in a secure surroundings has deviated in the same manner as in Eastern European samples (Schwartz and Bardi, 1997, Bardi and Schwartz, 1996). 


\section{THE AIM OF THE STUDY}

In the current study I investigate three demographic variables: country, age, and education as predictors of human values. As people get older, they have more tendency to be away of social and public networks and less willing to take risks and face challenges, instead, they have more obligation to routines (Tyler and Shuller, 1991). Based on this, I hypothesize that age has a positive and significant relationship with conservation values (tradition, conformity, and security), negative relationship with openness to change values (self-direction, stimulation), and negative relationship with hedonism. As people grow old, they demand attaining a stable position. They tend to be less anxious and more focused on the prosperity of others (Veroff, Reuman, and Feld, 1984). Thus, I expect that age has a positive relationship with self-transcendence values (benevolence, universalism) and negative relationship with self-enhancement values (power, achievement). Finally, based on previous literature I expect that educational level is related to higher openness, flexibility, and self-direction values (Kohn \& Schooler 1983). Conversely, being educated is expected to weaken conformity and tradition values by questioning fundamental norms, beliefs and traditions.

Based on the above considerations, I propose the following questions to be addressed in the current study. What is the difference in terms of values between Iran and Poland? Does age have a significant positive relationship with the importance of helping the people, looking after environment, tradition, behaving properly and living in secure surroundings? Dose age have a negative relationship with the importance of adventures and taking risks, thinking up new ideas, having a good time being rich and being very successful? Dose age moderate the relationship between country and the importance of thinking up new ideas? Dose age moderate the relationship between country and the importance of helping the people? Does education has a significant positive relationship with the importance of thinking up new ideas and adventures and taking risks? Does education has negative link with the importance of tradition? And finally does education moderate the relationship between country and the importance of tradition?

\section{METHOD}

\section{Participants and Procedure}

Data in the current study involved respondents from national samples of Iran and Poland who took part in the fifth (2005-2009) wave of the World Value Survey (WVS). The World Values Survey (www.worldvaluessurvey.org) is a worldwide research studying various values and their influence on societal and political life (http://www.worldvaluessurvey.org). I chose to use the data of WVS because it is one of the few international social surveys that contains the data for Iran.

The following respondents from the current study were removed from the analyses: 1 . those younger than 20 years old and 2. Those older than 69 years old. The sample size in Iran equaled $\mathrm{N}=2577$ and in Poland it equaled $\mathrm{N}=880$. Therefore, $74.6 \%$ of respondents were Iranian and $25.4 \%$ of them were Polish. Besides, $49.6 \%$ were male and $50.4 \%$ of them were female. I summarized the features of samples in Table 2. I included $99.39 \%$ of respondents $(\mathrm{N}=3435.8)$ who responded to 10 human value questions. 
Table 2. Share of respondents by region/country by gender and be age (n, percentage).

\begin{tabular}{|c|c|c|c|c|c|c|c|}
\hline \multirow{2}{*}{ Country } & \multicolumn{2}{|c|}{ Gender } & \multicolumn{5}{|c|}{ Age } \\
\hline & Male & Female & $20-29$ & $30-39$ & $40-49$ & $50-59$ & $60-69$ \\
\hline Iran & $1282(50.1 \%)$ & $1295(49.9 \%)$ & $1013(44.1 \%)$ & $633(27.6 \%)$ & $392(17.1 \%)$ & $190(8.3 \%)$ & $67(2.9 \%)$ \\
\hline Poland & $433(47.6 \%)$ & $447(52.4 \%)$ & $198(23.9 \%)$ & $153(18.5 \%)$ & $210(25.3 \%)$ & $164(19.8 \%)$ & $104(12.5 \%)$ \\
\hline
\end{tabular}

\section{Measurement}

The dependent variables for my analyses were: 1) the importance of being rich (power value), 2) the importance of adventures and taking risks (stimulation value), 3) the importance of being very successful (achievement value), 4) the importance of thinking up new ideas (self-direction value), 5) the importance of having a good time (hedonism value), 6) the importance of living in a secure surroundings (security value), 7) the importance of tradition (tradition value), 8) the importance of behaving properly (conformity value), 9) the importance of helping the people (benevolence value), 10) the importance of looking after environment (universalism value). Each of these values was measured in the form of third person statement, for instance: "It is important to this person to always behave properly" or "It is important to this person looking after environment" (response scale from 1 - not at all like me to 6 - very much like me) ${ }^{1}$. Following recommendations of Schwartz (2003) values were ipsatized, which reduces the impact of response styles that might affect the preferences for the usage of response scales. It is especially important to control for response bias in cross-cultural research, as representatives of different cultures might show different response styles (Wieczorkowska-Wierzbinska, Wierzbinski, \& Kuzminska, 2014). Predictor variables were: age, country (1: Iran vs. 2: Poland), and education (in years). I excluded respondents with age above 70 years old and below 20 years old.

\section{RESULTS}

An independent samples t-test was conducted to determine the significance of difference between Iranians and Poles in their age, education, and basic human values. The results of these analyses can be seen in Table 3. Since Levene's test of homogeneity of variance was significant for all variables, a t statistic assuming unequal variances was analyzed.

Iranian sample had a similar level of education measured in years of schooling $(\mathrm{M}=11.15, \mathrm{SD}=3.01)$ to the Polish sample $(\mathrm{M}=11.09, \mathrm{SD}=2.12)$. Poles sample was older than Iranian sample (Poland: $\mathrm{M}=40.96, \mathrm{SD}=1.34$; Iran: $\mathrm{M}=32.09, \mathrm{SD}=11.60$ ).

Table 3. Results of Independent Samples t-test for Iran and Poland

\begin{tabular}{lcccccc}
\hline & $\begin{array}{c}\text { Iran } \\
\text { Mean }\end{array}$ & $\begin{array}{c}\text { Poland } \\
\text { Mean }\end{array}$ & $\begin{array}{c}\text { Iran } \\
\text { Standard deviation }\end{array}$ & $\begin{array}{c}\text { Poland } \\
\text { Standard deviation }\end{array}$ & $t$ & $p$ \\
\hline Age & 32.09 & 40.96 & 11.60 & 14.42 & -16.51 & $<.001$ \\
Education & 11.15 & 11.09 & 3.01 & 2.12 & 0.68 & 0.50 \\
Gender & 1.50 & 1.52 & 0.500 & 0.500 & -1.352 & 0.18 \\
\hline
\end{tabular}

1 The above given response scales were recoded from the original version provided in WVS. 


\section{Values, Age, Country and Education: Relations across Cultural Groups}

In the next stage, I performed regression analyses to see if human values are different for Iran and Poland and if they are related to age and education. What is more, I checked if education and age moderates the relationship between country and these values. The results of regression analyses and the coefficients of the regression model are presented in Tables 4 to 13 .

Self-direction. There was no difference between Iran and Poland in valuing self-direction (important to think up new ideas). This value was predicted by education $(\beta=0.179, p<.001)-$ the higher the education the higher the self-direction value. This value was also slightly higher for men than for women $(\beta=-0.034, p=.044)$. This value was also significantly predicted by interaction between country and age, which is presented in Figure 2. In Iran, the older the respondents the more important this value was to them. In Poland, an opposite pattern was observed - importance of thinking up new ideas was reversely related to age. The regression model was significant and accounted for $4.4 \%$ of variability in self-direction value, $F(6,3399)=26.27, p<.001$ (see Table 4 ).

Table 4. Multiple regression coefficients predicting the importance of thinking up new ideas

\begin{tabular}{|c|c|c|c|c|}
\hline & \multicolumn{2}{|c|}{ Regression coefficients } & \multirow{2}{*}{$t$} & \multirow{2}{*}{$p$} \\
\hline & $\mathrm{B}$ & Beta & & \\
\hline Constant & 0.132 & & 7.115 & $<.001$ \\
\hline Country & 0.004 & 0.003 & 0.187 & .852 \\
\hline Age & -0.027 & -0.025 & -1.333 & .182 \\
\hline Education & 0.191 & 0.179 & 9.707 & $<.001$ \\
\hline Gender & -0.036 & -0.034 & -2.012 & .044 \\
\hline Country-Age & -0.063 & -0.066 & -3.541 & $<.001$ \\
\hline Country-education & -0.037 & -0.030 & -1.634 & .102 \\
\hline
\end{tabular}

Note: Country (1: Iran, 2: Poland), Gender (1: Male, 2: Female).

Figure 2. Interaction between age and country on the importance of thinking up new ideas

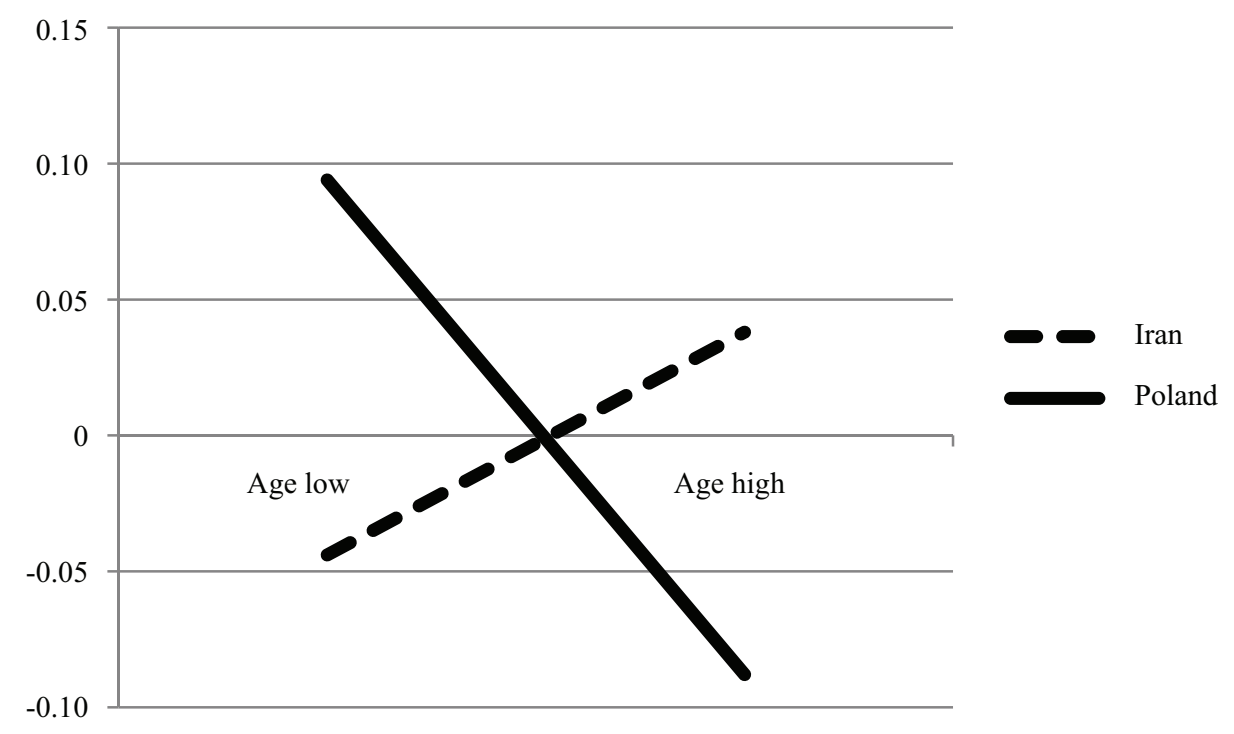


Stimulation. There was a difference between Iran and Poland in valuing adventure and taking risks, with Poles valuing stimulation more than Iranians $(\beta=0.130, p<.001)$. This value was predicted by education $(\beta=0.086, \mathrm{p}<.001)$ - the higher the education the higher the value of adventure and taking risks. This value was also higher for men than for women $(\beta=-0.098$, $p<.001)$. Moreover, the younger the respondents the more important this value was to them $(b=-0.215, p<.001)$. The regression model was significant and accounted for $7.4 \%$ of variability in stimulation value, $F(6,3403)=46.143, p<.001$ (see Table 5$)$.

Table 5. Multiple regression coefficients predicting the importance of adventure and taking risks

\begin{tabular}{|c|c|c|c|c|}
\hline & \multicolumn{2}{|c|}{ Regression coefficients } & \multirow{2}{*}{$t$} & \multirow{2}{*}{$p$} \\
\hline & $\mathrm{B}$ & Beta & & \\
\hline (Constant) & -0.864 & & -38.608 & $<.001$ \\
\hline Country & 0.169 & 0.130 & 7.313 & $<.001$ \\
\hline Age & -0.279 & -0.215 & -11.439 & $<.001$ \\
\hline Education & 0.112 & 0.086 & 4.721 & $<.001$ \\
\hline Gender & -0.128 & -0.098 & -5.917 & $<.001$ \\
\hline Country-Age & 0.004 & 0.004 & 0.207 & 0.836 \\
\hline Country-education & -0.018 & -0.012 & -0.669 & 0.504 \\
\hline
\end{tabular}

Note: Country (1: Iran, 2: Poland), Gender (1: Male, 2: Female).

Hedonism. There was significant difference between Iran and Poland in the importance of having a good time, with Poles embracing this value more than Iranians $(\beta=0.074, p<.001)$. This value was predicted by age $(\beta=-0.183, p<.001)$ - younger respondents valued having a good time more than older respondents. Besides, this value was higher for men than for women $(\beta=-0.049$, $p=.004)$. The regression model was significant and accounted for $3.3 \%$ of variability in hedonism value, $F(6,3398)=19.552, p<.001($ see Table 6$)$.

Table 6. Multiple regression coefficients predicting the importance of having a good time

\begin{tabular}{|c|c|c|c|c|}
\hline & \multicolumn{2}{|c|}{ Regression coefficients } & \multirow{2}{*}{$t$} & \multirow{2}{*}{$p$} \\
\hline & $\mathrm{B}$ & Beta & & \\
\hline (Constant) & -0.988 & & -45.505 & $<.001$ \\
\hline Country & 0.091 & 0.074 & 4.047 & $<.001$ \\
\hline Age & -0.226 & -0.183 & -9.539 & $<.001$ \\
\hline Education & -0.013 & -0.011 & -0.586 & 0.558 \\
\hline Gender & -0.061 & -0.049 & -2.899 & 0.004 \\
\hline Country-Age & -0.013 & -0.012 & -0.631 & 0.528 \\
\hline Country-education & -0.022 & -0.015 & -0.817 & 0.414 \\
\hline
\end{tabular}

Note: Country (1: Iran, 2: Poland), Gender (1: Male, 2: Female). 
Power. There was a significant difference between Iran and Poland in the importance of being rich (power value), with Iranians embracing this value to a greater extent than Poles $(\beta=-0.165$, $p<.001)$. This value was also predicted by age $(\beta=-0.119, p<.001)$ - younger respondents attached more importance to being rich. Moreover, this value was higher for men than for women $(\beta=-0.058, p=.001)$. Furthermore, it has been predicted by an interaction between country and age $(\beta=0.046, p=0.014)$, which can be observed in Figure 3. Among Iranians, younger respondents attach much higher importance to this value than older respondents. Polish respondents also follow the same pattern, but difference between younger and older respondents was much less pronounced. The regression model was significant and accounted for $5 \%$ of variability in power value, $F(6,3408)=30.135, p<.001($ see Table 7$)$.

Table 7. Multiple regression coefficients predicting the importance of being rich

\begin{tabular}{|c|c|c|c|c|}
\hline & \multicolumn{2}{|c|}{ Regression coefficients } & \multirow{2}{*}{$t$} & \multirow{2}{*}{$p$} \\
\hline & $\mathrm{B}$ & Beta & & \\
\hline (Constant) & -0.833 & & -39.044 & $<.001$ \\
\hline Country & -0.201 & -0.165 & -9.121 & $<.001$ \\
\hline Age & -0.146 & -0.119 & -6.279 & $<.001$ \\
\hline Education & -0.007 & -0.006 & -0.325 & 0.745 \\
\hline Gender & -0.071 & -0.058 & -3.415 & 0.001 \\
\hline Country-Age & 0.050 & 0.046 & 2.471 & 0.014 \\
\hline Country-education & -0.004 & -0.002 & -0.136 & 0.892 \\
\hline
\end{tabular}

Note: Country (1: Iran, 2: Poland), Gender (1: Male, 2: Female).

Figure 3. Interaction between age and country on the importance of being rich

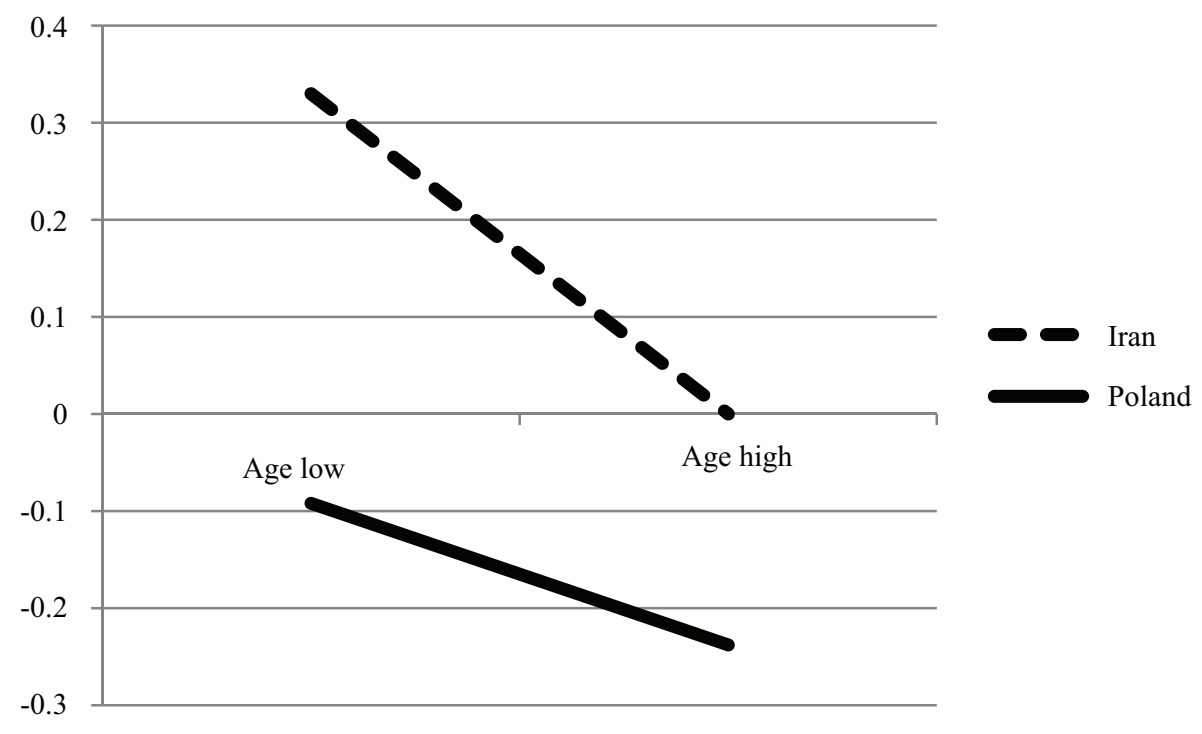

Achievement. There was a difference between Iran and Poland in attaching importance to being successful, with Poles valuing achievement more than Iranians $(\beta=0.128, p<.001)$. This value was also predicted by age $(\beta=-0.088, p<.001)$ - younger respondents valued achievement more 
than older respondents. The regression model was significant and accounted for $1.6 \%$ of variability in achievement value, $F(6,3399)=10.520, p<.001$ (see Table 8$)$.

Table 8. Multiple regression coefficients predicting the importance of being very successful

\begin{tabular}{|c|c|c|c|c|}
\hline & \multicolumn{2}{|c|}{ Regression coefficients } & \multirow{2}{*}{$t$} & \multirow{2}{*}{$p$} \\
\hline & $\mathrm{B}$ & Beta & & \\
\hline (Constant) & -0.158 & & -8.140 & $<.001$ \\
\hline Country & 0.139 & 0.128 & 6.941 & $<.001$ \\
\hline Age & -0.096 & -0.088 & -4.552 & $<.001$ \\
\hline Education & 0.003 & 0.003 & 0.139 & 0.889 \\
\hline Gender & 0.011 & 0.010 & 0.578 & 0.563 \\
\hline Country-Age & 0.017 & 0.017 & 0.902 & 0.367 \\
\hline Country-education & 0.012 & 0.009 & 0.494 & 0.621 \\
\hline
\end{tabular}

Note: Country (1: Iran, 2: Poland), Gender (1: Male, 2: Female).

Security. There was significant difference between Iran and Poland in the importance of security value, with Iranians embracing this value to a greater extent than Poles $(\beta=-0.106, p<.001)$. This value was also predicted by age $(\beta=0.149, p<.001)$ - living in a secure surroundings is more important to older respondents. It was also higher for women than for men $(\beta=0.044, p=.009)$. The regression model was significant and accounted for $2.4 \%$ of variability in living in security value, $F(6,3406)=14.110, p<.001$ (see Table 9).

Table 9. Multiple regression coefficients predicting the importance of living in secure surroundings

\begin{tabular}{|c|c|c|c|c|}
\hline & \multicolumn{2}{|c|}{ Regression coefficients } & \multirow{2}{*}{$t$} & \multirow{2}{*}{$p$} \\
\hline & $\mathrm{B}$ & Beta & & \\
\hline (Constant) & 0.669 & & 38.961 & $<.001$ \\
\hline Country & -0.107 & -0.106 & -5.780 & $<.001$ \\
\hline Age & 0.152 & 0.149 & 7.739 & $<.001$ \\
\hline Education & 0.026 & 0.026 & 1.384 & 0.166 \\
\hline Gender & 0.045 & 0.044 & 2.605 & 0.009 \\
\hline Country-Age & -0.004 & -0.005 & -0.262 & 0.794 \\
\hline Country-education & -0.042 & -0.035 & -1.924 & 0.054 \\
\hline
\end{tabular}

Note: Country (1: Iran, 2: Poland), Gender (1: Male, 2: Female).

Conformity. There was significant difference between Iran and Poland in the importance of always behaving properly, with Iranians embracing conformity value to a greater extent than Poles $(\beta=-0.201, p<.001)$. This value was predicted by age $(\beta=0.116, p<.001)$ - older respondents attach more importance to conformity than younger ones. Additionally, this value was higher for 
women than for men $(\beta=0.057, p=.001)$. Furthermore, this value was predicted by education $(\beta=-0.085, p<.001)$ the higher the education the lower the value of always behaving properly. The regression model was significant and accounted for $5.3 \%$ of variability in conformity value, $\mathrm{F}(6,3403)=32.664, p<.001($ see Table 10$)$.

Table 10. Multiple regression coefficients predicting the importance of always behaving properly

\begin{tabular}{|c|c|c|c|c|}
\hline & \multicolumn{2}{|c|}{ Regression coefficients } & \multirow{2}{*}{$t$} & \multirow{2}{*}{$p$} \\
\hline & $\mathrm{B}$ & Beta & & \\
\hline (Constant) & 0.447 & & 25.909 & $<.001$ \\
\hline Country & -0.199 & -0.201 & -11.118 & $<.001$ \\
\hline Age & 0.115 & 0.116 & 6.127 & $<.001$ \\
\hline Education & -0.084 & -0.085 & -4.626 & $<.001$ \\
\hline Gender & 0.057 & 0.057 & 3.391 & 0.001 \\
\hline Country-Age & 0.011 & 0.012 & 0.640 & 0.522 \\
\hline Country-education & -0.013 & -0.011 & -0.598 & 0.550 \\
\hline
\end{tabular}

Note: Country (1: Iran, 2: Poland), Gender (1: Male, 2: Female).

Tradition. There was a difference between Iran and Poland in valuing tradition, with Poles embracing it to a greater extent than Iranians $(\beta=0.082, p<0.001)$. This value was predicted by education $(\beta=-0.142, p<0.001)$ - the lower the education the higher the value of tradition. This value was also higher for women than for men $(\beta=0.068, p<0.001)$. Furthermore, older respondents also attach more importance on tradition than younger respondents $(\beta=0.167, p<0.001)$. Tradition was also significantly predicted by an interaction between country and education, which is presented in Figure 4. In Iran, respondents with lower education value tradition slightly more than respondents with higher education. In Iran, the importance of tradition decreases as the level of education increases much more steeply than in Poland. The regression model was significant and accounted for $10.1 \%$ of variability in tradition value, $F(6,3406)=64.043, p<.001$ (see Table 11 ).

Table 11. Multiple regression coefficients predicting the importance of tradition

\begin{tabular}{|c|c|c|c|c|}
\hline & \multicolumn{2}{|c|}{ Regression coefficients } & \multirow{2}{*}{$t$} & \multirow{2}{*}{$p$} \\
\hline & $\mathrm{B}$ & Beta & & \\
\hline (Constant) & 0.506 & & 26.668 & $<.001$ \\
\hline Country & 0.092 & 0.082 & 4.678 & $<.001$ \\
\hline Age & 0.187 & 0.167 & 9.046 & $<.001$ \\
\hline Education & -0.160 & -0.142 & -7.943 & $<.001$ \\
\hline Gender & 0.076 & 0.068 & 4.117 & $<.001$ \\
\hline Country-Age & 0.018 & 0.018 & 0.983 & 0.326 \\
\hline Country-education & 0.107 & 0.081 & 4.602 & $<.001$ \\
\hline
\end{tabular}

Note: Country (1: Iran, 2: Poland), Gender (1: Male, 2: Female). 
Figure 4. Interaction between education and country on the importance of tradition

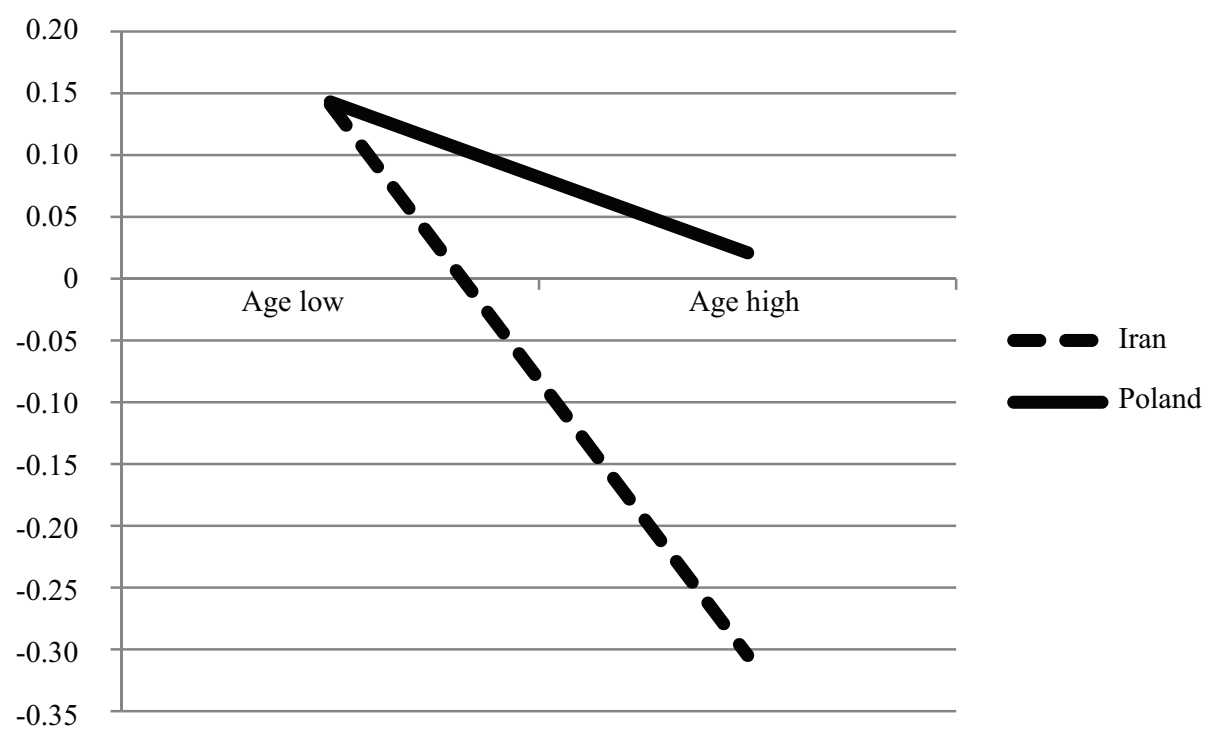

Benevolence. There was a significant difference between Iran and Poland in valuing to help people, with Poles embracing this value to a greater extent than Iranians $(\beta=0.064, p<.001)$. This value was also predicted by education $(\beta=-0.094, p<.001)$ - the higher the education the lower the value of helping people. This value was also higher for women than for men $(\beta=0.152$, $p<.001)$. Benevolence was also significantly predicted by interaction between country and age, which is presented in Figure 5. In both countries the older the respondents the more important this value was to them. However, in Iran younger respondents expressed an even lower importance of benevolence compared to the older ones. The regression model was significant and accounted for $5.5 \%$ of variability benevolence value, $\mathrm{F}(6,3383)=33.788, p<.001$ (see Table 12 ).

Table 12. Multiple regression coefficients predicting the importance of helping people

\begin{tabular}{|c|c|c|c|c|}
\hline & \multicolumn{2}{|c|}{ Regression coefficients } & \multirow{2}{*}{$t$} & \multirow{2}{*}{$p$} \\
\hline & $\mathrm{B}$ & Beta & & \\
\hline (Constant) & 0.503 & & 31.453 & $<.001$ \\
\hline Country & 0.059 & 0.064 & 3.563 & $<.001$ \\
\hline Age & 0.139 & 0.152 & 7.992 & $<.001$ \\
\hline Education & -0.087 & -0.094 & -5.126 & $<.001$ \\
\hline Gender & 0.058 & 0.064 & 3.771 & $<.001$ \\
\hline Country-Age & -0.039 & -0.047 & -2.521 & 0.012 \\
\hline Country-education & 0.035 & 0.032 & 1.760 & 0.078 \\
\hline
\end{tabular}

Note: Country (1: Iran, 2: Poland), Gender (1: Male, 2: Female). 
Figure 5. Interaction between age and country on the importance of helping people

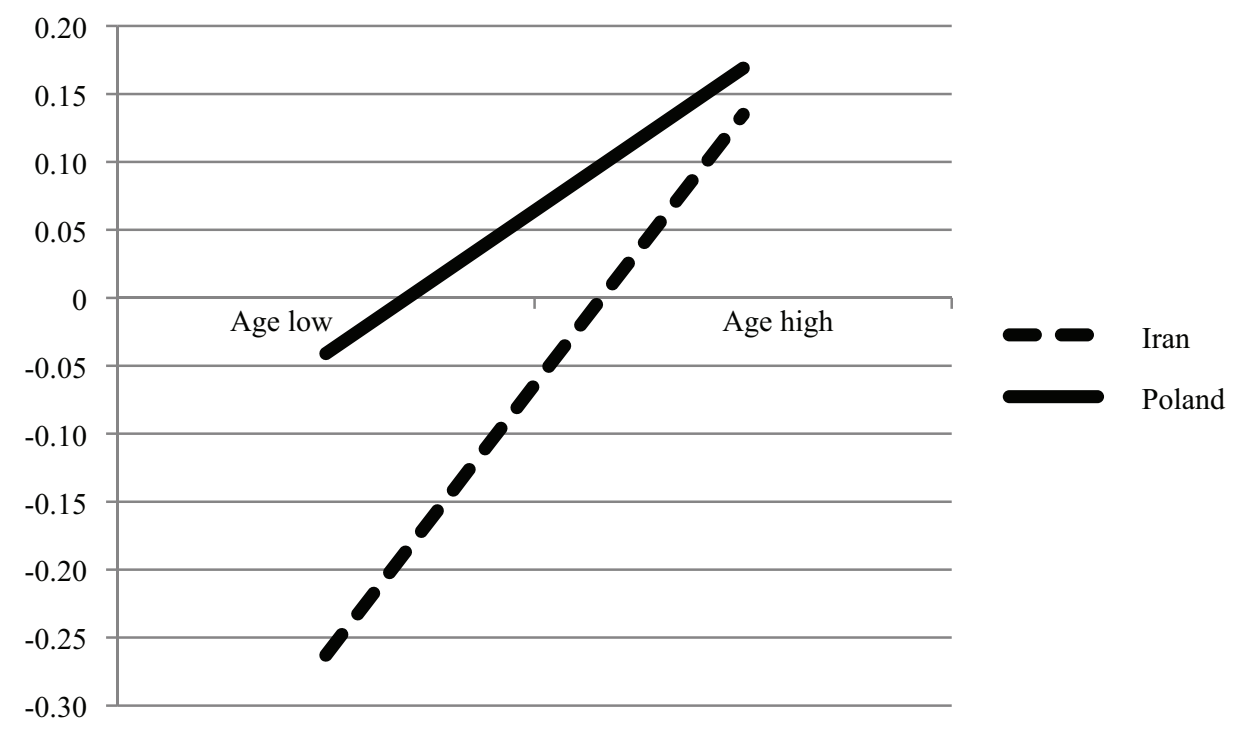

Universalism. There was significant difference between Iran and Poland in the importance of looking after environment, with Iranians valuing universalism to a greater extent than Poles $(\beta=-0.047, p=.010)$. This value was also predicted by age $(\beta=0.180, p<.001)$ - older respondents attach more importance on looking after environment than younger ones. Moreover, universalism value was higher for women than for men $(\beta=0.047, p=0.006)$. The regression model was significant and accounted for $3.1 \%$ of variability in universalism value, $F(6,3403)=19.312$, $p<.001$ (see Table 13).

Table 13. Multiple regression coefficients predicting the importance of looking after environment

\begin{tabular}{|c|c|c|c|c|}
\hline & \multicolumn{2}{|c|}{ Regression coefficients } & \multirow{2}{*}{$t$} & \multirow{2}{*}{$p$} \\
\hline & $\mathrm{B}$ & Beta & & \\
\hline (Constant) & 0.549 & & 33.413 & $<.001$ \\
\hline Country & -0.044 & -0.047 & -2.590 & 0.010 \\
\hline Age & 0.169 & 0.180 & 9.403 & $<.001$ \\
\hline Education & 0.016 & 0.017 & 0.928 & 0.354 \\
\hline Gender & 0.044 & 0.047 & 2.766 & .0 .006 \\
\hline Country-Age & 0.025 & 0.030 & 1.602 & 0.109 \\
\hline Country-education & -0.013 & -0.011 & -0.620 & 0.535 \\
\hline
\end{tabular}

Note: Country (1: Iran, 2: Poland), Gender (1: Male, 2: Female).

\section{DISCUSSION}

The main purpose of the present study was to investigate the differences in basic human values between Iran and Poland - a comparison that has not been undertaken in previous studies. Additionally, I check how human values in these two countries vary as a result of age (socialization if different sociopolitical contexts) and the level of education. 
The results values between showed that the differences in Poland and Iran were evident for all studied values, except for self-direction. The results indicated that Iranians were more likely to embrace power, security, conformity, and universalism values. Poles, on the other hand, reported higher importance of stimulation, hedonism, achievement, tradition, and benevolence values.

Iran culture over the Shah regime was closed to Western culture and regime was trying to develop the views that traditional and Islamic beliefs belong to the past. However, after Islamic revolution in 1978-79, Islamic values have been disseminated again. New government has tried to emphasize more on obtaining human dignity and values rather than on materialism. As a consequence, conformity and priority of behaving properly, avoiding harm others and violating social expectations or norms, being obedient and polite, honoring parents and elders, self-discipline, benefit of social cohesiveness, work in harmony, justice and equity, belonging, humility and simplicity have been reinforced. Theses principals are transmitted by schools, families and many different religious ceremonies all for the purpose of underlining collectivism and being liberated of external and foreign influences (Abbas \& Amirshahi, 2002). Therefore, safety, harmony, and stability of society and relationships, national security, social order, sense of belonging, family security, understanding, appreciation, tolerance and protection for the welfare of all people and for nature has become more imperative in Iran today. Although, the process of nationalization and reconstructing has changed distribution of power in Iran, it led to great deal of power distance in Iran society. According to Javadian and Dastmalchian (2003) extreme advantages and positions has been given to people in places of power and authority. As a result at the end it can be seen that institutional collectivism was not really a strong suit of Iranians.

In this study, age moderated the relationship between country and self-direction, power, and benevolence values. As it can be observed the importance of thinking up to new ideas, novelty and change in life is more important when you are young, but the results in Iran is a bit different. Young generation attach not so much important in self-direction while old generation pay more attention to this value. This also has been proven in Delkhamosh and Ahmadi Mobarake (2012) study. It could be somehow related to the different education that older generation had in a different era, they had been taught that traditional principals belong to our past. Consequently, they attach more importance to this value. Nevertheless, this results might be changed if we use data related to this decade. With developing technology, mass media, internet, etc. people especially younger generation has obtained more knowledge about the necessities of being open to new ideas. Moreover, based on what have been told, young generation value power and have dominance on other people way more that old generation and it origins from the perspective they have taken during the years of living in Iran by observing all the privileges that people in authority have possessed. Furthermore, preservation and enhancement of the welfare of people with whom one is in frequent personal contact and benevolence getting more importance as people growing old. It is mostly roots in nowadays hectic lifestyle. Younger people usually find less time and resources to devote to people who they do not know.

Education also moderated the relationship between country and tradition value, it is observable that there is a large gap between higher education and lower education people in terms of valuing into tradition in Iran. As people gain more knowledge, use more internet, media and get to know what is going on around the world they less tend to value tradition.

In addition to country differences, age differences are evident for all values except the importance of self-direction value. Unsurprisingly, higher importance of benevolence, universalism, tradition, conformity, and security was related to being older, while higher level of stimulation, hedonism, power and achievement was higher among the younger respondents. The fact that young people value success more than older people has been demonstrated in different studies that younger generations are exceedingly motivated and achievement-oriented (e.g., Conger, 1997; Tulgan, 1997). 
The importance of looking after environment was more highly appreciated among older people in both analyzed countries. However, previous research (e.g., DiDio, Saragovi, Koestner, and Aube, 1996; Rokeach, 1973; Feather, 1987) showed that the importance of looking after the environment has been mostly unchanged from one generation to the other.

My findings indicated that older people in Iran and Poland placed more importance on tradition than younger generation, which confirmed previous research results (Lyons, Duxbury, and Higgins, 2005; DiDio, Saragovi, Koestner, and Aube, 1996; Rokeach, 1973; Feather, 1987). In addition, in this study, age was significantly and positively related with the importance of conformity and security, which is a novel result, compared to previous studies which the importance of conformity and security is not positively related to age (e.g., Lyons, Duxbury, and Higgins, 2005; DiDio, Saragovi, Koestner, and Aube, 1996; Rokeach, 1973; Feather, 1987). What is more, power and stimulation values were negatively related to age, which is consistent with other studies, which showed that a younger generation (particularly men) place more importance on being rich, powerful, and autonomous because they feel consistently disempowered by the deficiency of occupation and disadvantageous economic situation (Lyons, Duxbury, and Higgins, 2005).

In this study, we found a significant and negative relationship between age and the importance of adventures and taking risks. This generational patterns is also authenticated in Lyons, Duxbury, and Higgins study in 2005. Younger generation is valuing happiness and enjoyment, they always seek out new challenges and changes in life, whilst older people are more interested to be in secure surroundings and to behave properly. I also found a positive significant relationship between the importance of helping the people and age. Younger people were raised to be more independent and self-reliant (Lyons, Duxbury, and Higgins, 2005).

Moreover, self-direction, stimulation, conformity, benevolence, hedonism, security and tradition values were significantly related with education. Higher education can increase openness to change values and decrease conservation values, and this can be observed in other studies (i.e., GonzalezRodriguez, Fernandez, Spers, and Leite, 2016).

\section{Limitation and Future Research}

The nature of sample may have had an influence on the results, because the analysis of sample characteristics clearly reveals that it was not representative of the population, especially the Iranian sample. For example, in Iran there were more respondents than in Poland (Iran $=72.7 \%$ and Poland $=$ $27.3 \%$ of the total sample) and it is not exactly obvious why. Besides, Iranian respondents have been shown to be 10 years younger than Polish respondents. Also, most of Iranian respondents (72.8\%) lived in urban areas, while 42.4 percent of Polish respondents lived in small cities, while 57.6 percent lives in big cities. The most striking difference is the level of education. Highest level of education was claimed by $20.2 \%$ of the respondents in Iran vs. $4.6 \%$ in Poland. All this demonstrates the unrepresentativeness of the sample, which can stem from the participation of mostly urban residents in Iran. All these issues can mislead our results, therefore, further research and investigations is needed.

\section{Literature}

Ali, A. J., \& Amirshahi, M. (2002). The Iranian manager: Work values and orientations. Journal of Business Ethics, 40(2), 133-143.

Bardi, A., \& Schwartz, S. H. (1996). Relations among Sociopolitical Values in Eastern Europe: Effects of the Communist Experience? Political Psychology, 17(3), 525-549. doi: 10.2307/3791967 
Bilsky, W., Janik, M., \& Schwartz, S. H. (2011). The Structural Organization of Human Values-Evidence from Three Rounds of the European Social Survey (ESS). Journal of Cross-Cultural Psychology, 42(5), 759-776. doi: $10.1177 / 0022022110362757$

Cieciuch, J., \& Davidov, E. (2012). A comparison of the invariance properties of the PVQ-40 and the PVQ-21 to measure human values across German and Polish Samples. Journal of the European Survey Research Association, 6(1), 12. doi: 10.18148/srm/2012.v6i1.5091

Conger, J. (1997). The generation game. Management, 44(9), 72-73.

Di Dio, L., Saragovi, C., Koestner, R., \& Aubé, J. (1996). Linking personal values to gender. Sex Roles, 34(9), 621-636. doi: 10.1007/bf01551498

Dobewall, H., \& Rudnev, M. (2014). Common and Unique Features of Schwartz's and Inglehart's Value Theories at the Country and Individual Levels. Cross-Cultural Research, 48(1), 45-77. doi: 10.1177/10693971134 93584

Feather, N. T. (1987). Gender Differences in Values: Implications of the Expectancy-Value Model, Berlin, Heidelberg.

Fischer, R., \& Boer, D. (2015). Motivational Basis of Personality Traits: A Meta-Analysis of Value-Personality Correlations. Journal of Personality, 83(5), 491-510. doi: doi:10.1111/jopy.12125

Fontaine, J. R. J., Poortinga, Y. H., Delbeke, L., \& Schwartz, S. H. (2008). Structural Equivalence of the Values Domain Across Cultures:Distinguishing Sampling Fluctuations From Meaningful Variation. Journal of Cross-Cultural Psychology, 39(4), 345-365. doi: 10.1177/0022022108318112

Gonzalez-Rodriguez, M. D. R., Diaz-Fernandez, M. D. C., Spers, V. R. E., \& Leite, M. D. S. (2016). Relation between background variables, values and corporate social responsibility. Revista de Administração de Empresas, 56(1), 8-19.

Haslam, N. (2004). Relational Models Theory: A Contemporary Overview, New Jersey: Lawrence Erlbaum Associates.

Herskovits, M. J. (1955). Cultural anthropology, Oxford, England: Knopf.

Javidan, M., \& Dastmalchian, A. (2003). Culture and leadership in Iran: The land of individual achievers, strong family ties, and powerful elite. Academy of Management Perspectives, 17(4), 127-142.

Kohn, M. L., \& Schooler, C. (1983). Work and personality: An inquiry into the impact of social stratification: Ablex Pub.

Lyons, S., Duxbury, L., \& Higgins, C. (2005). Are Gender Differences in Basic Human Values a Generational Phenomenon? Sex Roles, 53(9), 763-778. doi: 10.1007/s11199-005-7740-4

Prince-Gibson, E., \& Schwartz, S. H. (1998). Value Priorities and Gender. Social Psychology Quarterly, 61(1), 49-67. doi: 10.2307/2787057

Rokeach, M. (1973). The nature of human values. New York, NY, US: Free Press.

Schwartz, S. H. (1992). Universals in the Content and Structure of Values: Theoretical Advances and Empirical Tests in 20 Countries. In M. P. Zanna (Ed.), Advances in Experimental Social Psychology (Vol. 25, pp. 1-65): Academic Press.

Schwartz, S. H. (1994). Are there universal aspects in the structure and contents of human values? Journal of Social Issues, 50(4), 19-45. doi: 10.1111/j.1540-4560.1994.tb01196.x

Schwartz, S. H., \& Bardi, A. (1997). Influences of Adaptation to Communist Rule on Value Priorities in Eastern Europe. Political Psychology, 18(2), 385-410.

Schwartz, S. H., \& Bardi, A. (2001). Value Hierarchies Across Cultures:Taking a Similarities Perspective. Journal of Cross-Cultural Psychology, 32(3), 268-290. doi: 10.1177/0022022101032003002

Schwartz, S. H., \& Huismans, S. (1995). Value Priorities and Religiosity in Four Western Religions. Social Psychology Quarterly, 58(2), 88-107. doi: 10.2307/2787148

Schwartz, S. H., \& Rubel-Lifschitz, T. (2009). Cross-national variation in the size of sex differences in values: effects of gender equality. Journal of personality and social psychology, 97(1), 171-185. doi: 10.1037/ a0015546

Schwartz, S. H., \& Sagiv, L. (1995). Identifying Culture-Specifics in the Content and Structure of Values. Journal of Cross-Cultural Psychology, 26(1), 92-116. doi: 10.1177/0022022195261007

Schwartz, S. H., Caprara, G. V., \& Vecchione, M. (2010). Basic Personal Values, Core Political Values, and Voting: A Longitudinal Analysis. Political Psychology, 31(3), 421-452.

Sortheix, F. M., \& Lönnqvist, J.-E. (2014). Personal Value Priorities and Life Satisfaction in Europe:The Moderating Role of Socioeconomic Development. Journal of Cross-Cultural Psychology, 45(2), 282-299. doi: $10.1177 / 0022022113504621$

Tulgan, B. (1997). The manager's pocket guide to Generation X: Human Resource Development. Amherst: HRD Press. 
Vauclair, C.-M., Fischer, R., Ferreira, M. C., Guerra, V., Hößler, U., Karabati, S., . . Spieß, E. (2015). What Kinds of Value Motives Guide People in Their Moral Attitudes? The Role of Personal and Prescriptive Values at the Culture Level and Individual Level. Journal of Cross-Cultural Psychology, 46(2), 211-228. doi: $10.1177 / 0022022114557487$

Veroff, J., Reuman, D., \& Feld, S. (1984). Motives in American men and women across the adult life span. Developmental psychology, 20(6), 1142.

Verplanken, B., \& Holland, R. W. (2002). Motivated decision making: effects of activation and self-centrality of values on choices and behavior. Journal of personality and social psychology, 82(3), 434-447.

Wieczorkowska-Wierzbińska, G., Wierzbiński, J., Kuzminska, A. (2014). Porównywalność danych zebranych w różnych krajach. Psychologia Społeczna, 2(29), 128-143. 